\title{
THE RETURN OF THE BEEN-TO, THE BRINGER OF THE DIASPORA Isabel Gil Naveira
}

Universidad de Oviedo

\begin{abstract}
Most male characters in the exile, analysed from a Post-Colonial perspective, were usually classified as either suffering from a neo-colonial process, and therefore rejecting tradition, or as keeping tradition and longing for going back to a patriarchal society. In this article, I aim to establish how Ama Ata Aidoo, in her play The Dilemma of a Ghost (1965), represents the feelings of unrootedness, loss and guilt associated to the main male character's return to Africa. The use of the social and personal consequences that his comeback home to a matrilineal family has, will uncover the relation established between his family and his African American wife. In doing so, I will analyse how through an 'insignificant' song Aidoo tackles the controversial issue of the children of the diaspora and offers a solution to its rejection by the African population.
\end{abstract}

Keywords: Africa; African American; exile; diaspora; identity; silence; neocolonialism.

\section{Resumen}

La mayoría de los personajes masculinos en el exilio, analizados desde una perspectiva poscolonial, se solían clasificar en: aquellos bajo un proceso neocolonial, y que por tanto rechazaban la tradición, y aquellos que mantenían sus tradiciones y ansiaban volver a una sociedad patriarcal. En este artículo, intento establecer cómo Ama Ata Aidoo, en su obra The Dilemma of a Ghost (1965), representa los sentimientos de desarraigo, pérdida y culpabilidad asociados a la vuelta a África del personaje masculino principal. El uso de las consecuencias sociales y personales que su vuelta a una familia matrilineal tiene, destapará la relación establecida entre su familia y su esposa Afroamericana. De esta manera, analizaré cómo a través de una canción 'insignificante', Aidoo aborda la problemática cuestión de los hijos de la diáspora y ofrece una solución al rechazo por parte de la población africana.

Palabras clave: África; Afroamericana; exilio; diaspora; identidad; silencio; neocolonialismo. 
According to the South African writer Nadine Gordimer, African writers' novels and plays can be grouped in five recurrent categories, depending on the themes discussed within them: 'Countryman-Comes-to-Town', 'The Return of the Been-to', 'The Ancestors versus the Missionary', 'The Way it Was Back Home' and 'Let My People Go' (qtd. in Levitov 5). Despite these categories represent quite faithfully the problems that the African population had to confront during these last centuries, the existence of other important issues cannot be denied. This is the case of the question of diaspora ${ }^{1}$, which remains too controversial to be included as a category of its own.

"For almost four centuries Africans had endured traumas induced by the foreign encounter, most notably the transatlantic slave trade" (Gikandi, African 55), and much is still written about the colonial period that Africa suffered and about the "Middle Passage" and the consequences it had for the African Americans (see Aljoe; Christopher, Pybus and Rediker; Eltis and Richardson; Pedersen; Smallwood, among others). The concept of diaspora has also been largely studied (see Gikandi, Introduction; Gilroy, among others), as well as "[t]he theme of 'The Return Home,' ... has been a common one among diaspora writers" (Hill-Lubin 47) from the African-American point of view. In this respect, it is interesting to notice that African Americans have kept linguistic artefacts, semantic fields (see Baker) and

speech rituals ... which mask and disguise the true feelings and beliefs of the Afro-Americans, undergird a complex system of rebellion aimed at sustaining self-worth and psychic and physical freedom from EuroAmerica's cultural hegemony. The slave found this ability vital to his negotiation of life under severe repression and thus attempted through stories to pass this knowledge on. (Hope-Scott 257)

Moreover, "religio-mythological beliefs from many sectors of Africa came to the 'New World' between 1517 and 1873 with the enslaved peoples of the continent. These cultural elements survived the shock of transplantation and the subsequent break in continuity" (Lima 273). Nonetheless, the perspective of Africans in relation to slavery and how they dealt with the children of diaspora is still underdeveloped.

As Gaia Delpino explains, during the 1960s Ghana was the centre of the panAfricanist movement. Nevertheless, although Kwame Nkrumah" "employed the

\footnotetext{
${ }^{1}$ When I refer to the term 'diaspora' I do not refer to modern diasporas but the classical definition that resulted of slave trade and slavery.

${ }^{2}$ Kwame Krumah led Ghana to independence in 1957 and he was later on prime minister and president.
} 
language of kinship and racial unity to encourage African Americans to support the Ghanaian government ... Ghanaians were often suspicious of the political intentions of the newcomers ... A shared racial identity (based on the historical bond of slavery) was by no means a guarantor for acceptance [or] full integration" (Schramm 8) ${ }^{3}$. Quoting Bernth Lindfors, Hill-Lubin collects how "the 'AfroAmerican is nearly an invisible man' in the literature of Africans ... only a few African writers had even mentioned anything about Africans in the diaspora" (47). Few are the authors, who addressed this topic in their narratives; Hill-Lubin mentions main African authors like Wole Soyinka, Pepper Clarke and even Ngugi wa Thiong'O, although none of them addressed this question as eagerly and passionately as the Ghanaian writer Ama Ata Aidoo, who already in 1964 published her play The Dilemma of a Ghost. In an interview with Adeola James, Aidoo explained the reasons for her commitment to slavery and diaspora:

I think that the whole question of how it was that so many people could be enslaved and sold is very important. I've always thought that it is an area that must be proved. It holds one of the keys to our future... Until we have actually sorted out this whole question of African people, both on the continent and in the diaspora, we may be joking, simply going round in circles. (James 21)

In this article, grounded in Post-Colonial literary studies, I will consider how Aidoo serves herself of one of the categories described by Gordimer, 'The Return of the Been-to', to combine two problematic questions: that of the exile and the comeback home on the one hand, and the question of diaspora on the other. In doing so, Aidoo presents the reader with a young couple who have just arrived to Africa from the United States of America. Aidoo's male character, Ato, studies in the USA and feels forced to return to Africa following his family's desire. In the case of the female character, Ato's African-American wife, Eulalie, she is willing to go to Africa, but she will have to confront her real life in the continent. Inbetween these two characters, Aidoo includes an element, an 'insignificant' children's song, that appears all throughout the play. The use of this subterfuge will bring light to Aidoo's vision of what it means to come back to Africa for both an African man and an African-American woman. It is also my contention to

\footnotetext{
${ }^{3}$ Since the 1990s, the pan-Africanist movement aims have been rediscovered. Moreover, "[i]n 1992 and 1998 Jerry John Rawlings, head of the National Democratic Congress (NDC) governments, supported the establishment of the Pan-African Historical Theatre Festival ... to celebrate African cultures and "promote unity between Africans on the Continent and in the Diaspora (Ministry of Tourism and Diasporan Relations 2007: 2) ... [Years later t] Patriotic Party (NPP) governments of John Kufuor followed this "new pan-Africanist" policy and renamed in 2006 the Ghanaian Ministry of Tourism the "Ministry of Tourism and Diasporan Relations"” (Delpino 166-67).
} 
analyse how this situation will utterly affect Ato's assertiveness and hegemony, but will also address other problems in Africa: the children of the diaspora and the recovery of more egalitarian societies.

Presented for the first time "by the Students' Theatre [in] March 1964 at [...] the University of Ghana" (Dilemma 3), Aidoo's characters are used as a tool to address the silence created around the figure of the been-to and his god-like image-in Ato's case-and the silence established in Africa about slave trade and the children of the diaspora-in Eulalie's case. Moreover, the 'insignificant' song will also address the image of a ghost. According to Maureen N. Eke, for Ato's family Eulalie "represents the ghost from their past [that has] come to haunt them" (63); however, this paper will try to prove how Eulalie and Ato's family (mainly his mother) are the real protagonists of the story as Aidoo's solution against the rejection to the children of the diaspora includes the family and community's acceptance of Eulalie as their own. Hence, as the play moves forward, the ghost will no longer be connected to Eulalie, but to Ato and his inability to reconnect with his roots.

Taking into account the definition of exile, this term makes reference to "the state of being barred from one's native country, typically for political or punitive reasons" ("Exile" OED). However, Aidoo's play does not present us with a male character who has left his country of origin for political nor punitive reasons. When talking about exile I will make reference to an exile related to "the so-called Third World colonial who seeks the benefits and opportunities in a European country perceived as culturally superior, thus avoiding the socio-political situation at home" (Wilentz 162). Ato exiles of his own free will and has to fight against his desire to remain in the USA and follow the instructions of his family, who wants him to come back to Ghana.

As Ngugi wa Thiong'O collects "the seventies ... reveal what really had been happening in the sixties: the transition of imperialism from the colonial to the neocolonial stage" (161). In this respect, neo-colonialism affected African countries in the sense that

The increasingly open, naked financial, industrial ..., military and political interference of Western interests in the affairs of African countries with the active cooperation of the ruling regimes in the same countries, showed quite clearly that the so-called independence had only opened each of the African countries to wider imperialist interests. (Thiong'O 162)

However, this also affected many Africans who were under the influence of Western countries. As Fanon presented, "very often the national middle class does 
not follow [the] heroic, positive, fruitful and just path" (120-21) of putting forward the interests of the people, but they behave in a similar way to the colonialist for their own profit. When analysing male characters in the exile, from a PostColonial perspective, most of them are usually classified as either suffering from a neo-colonial process, and therefore rejecting tradition, or as keeping tradition and longing for going back to a patriarchal society (See Aidoo, Our Sister; Emecheta, In the Ditch, Kehinde, Second-Class; Ogot, The Graduate, among others). Either way, what seems to be clear is that when crossing geographical borders, men commonly find themselves crossing conceptual borders as well, and this usually leads them to lose part of their identity. In the case of Ato, he adopts this neo-colonial attitude with his family and his wife, what inevitably affects their post-exile experience.

Despite Aidoo does not explain the reasons for Ato's stay in the West and nothing is said about his previous life in Africa or his daily life in the USA, we know his exile was related to education, as he obtained a university degree. In order to analyze Ato's experiences in the exile and his comeback home more deeply it is necessary to take into account what this exile implied to his family. As Micere Githae Mugo points out "[ $t]$ he exile experience is indeed depicted as a rough journey which is exacting not just for the key traveler but also for the traveler's immediate family" (145). Ato's exile was a breaking-off for the family, and therefore, his return to Africa was supposed to mean a re-union for them. However, as the narrator of the play, The Bird of the Wayside ${ }^{4}$, explains to the audience, when Ato comes back he is a different person: "But if in the making of / One Scholar / Much is gone / You stranger do not know" (Dilemma 7). Ato's experiences in the USA seem to have a negative effect in the family, who suffered for his departure and continue suffering with his return. Ato's comeback home results in two main consequences that affect all the members of the family: an economical consequence and a social consequence.

When dealing with the economical consequence, it is important to consider that in many African societies it was common knowledge that many people who exiled never returned; consequently, when Ato arrives to Africa his family's uncertainty disappears. However, Aidoo raises a conflict of interest, as for supporting Ato to go to the USA to study his family had to spend all their resources. On his way back to Africa his family wants him to restore all the efforts they have made, and so the problems start when Ato expends some money to buy furniture and electrical devices ${ }^{5}$ for his new house instead of paying back all the

\footnotetext{
${ }^{4}$ The Bird of the Wayside represents common knowledge; it is used by Aidoo to help the audience interact with the characters of the play, as the Bird is the voice of the community.

${ }^{5}$ In the 1960 s electrical devices were luxury items in Africa.
} 
debts of the family at a time. Even Ato's mother, Esi, complaints about this situation:

Oh, Esi, of the luckless soul. ... Just consider the troubles I have had the school fees, the uniforms... ... The tears I have shed... ... My knees are callousing with bending before the rich... How my friends must be laughing behind me now. 'After all the fuss, she is poorer than ever before.' ... Apart from the lonely journeys I made to the unsympathetic rich, how often did I weep before your Uncles and great Uncles while everyone complained that my one son's education was ruining our home. (Dilemma 35)

The second consequence of Ato's exile and comeback home is related to the habits he has acquired during his exile and the social consequences this has in his relation to the family. Coming back to Africa also meant coming back to tradition, and for Ato this entailed an internal and an external conflict. It is internal because he feels he is in the middle of both ways of life: he is somehow attached and forced to recover his African traditions, but at the same time he embraces the new habits he has acquired in the USA, the habits of his African American wife. This conflict is also external, as he has to confront his African community's lack of understanding and rejection of these new habits and his African American wife's lack of understanding and rejection of some of the traditional habits. Through Ato's reactions Aidoo highlights a clear process of neo-colonization. The fact of living alone in a foreign country forced Ato to take his own decisions, without asking the family for advice. This was positive for his self-esteem, but it also led Ato to feel superior to his community, hence, he rejects the importance of the family and the community in his life. Ato is ashamed of his African traditions, which he considers inferior and even savage in comparison to the American ones, describing them as "primitive cultures" (Dilemma 26). As Naana Banyiwa Horne explains:

Apparently, a good student of colonial education, Ato, in his intercourse with both his wife and his indigenous family, manifests a flair for dominance, for talking down to people and striking the pose of the enlightened/colonizer/male in the presence of the ignorant/native/female (314).

Ato has taken an imperialist and patriarchal attitude, and when he comes back to Ghana he tries to impose his will upon his family and upon his wife, as well. After having lived in the exile, the African perspective of the world seems inadequate for him. 
Both Ato and his family consider him superior for his position as a 'beento ${ }^{6}$. Although the community is aware of the changes that exile provokes, as we have previously seen in The Bird of the Wayside comment, their silence is presented as common. Coming back as their economical Saviour, Ato is addressed as "our master, the white man himself" (Dilemma 14) and the only member in the family that does not believe in Ato's superiority as a 'been-to' is his sister Monka. Her ironic comments lead us to Aidoo's most fragrant criticism towards African society. Monka's words are fixed on opening the eyes and mouths of many African families that may find themselves in the same situation: "The way some people became scholars is fearful ... The master scholar was sitting on the chair studying, so he could not move off! After all, what is he learning? Is it the knowledge of the leopard skin?" (Dilemma 14). Aidoo's stage direction for the character of Monka presents her sucking her teeth to Ato, and despite he is presented laughing at the first part of Monka's comment, Aidoo is clearly criticizing those 'been-tos' who follow Ato's path and who, regarded as saviours and as semi-gods who would save their families, only feel ashamed of their own culture, their own nation and even their own family; at the same time, she criticizes the families for allowing them to do so, falling into the hands of neo-colonialism through their silence.

It is my assumption, therefore, that during his exile Ato has suffered a neocolonization process, and when he returns to Ghana he feels in-between two cultural backgrounds, the African one (the one of his childhood) and the American one (that he understands as superior). Through what seems to be an 'insignificant' song, a children's song, Aidoo gives us the key of Ato's attitude throughout the play. When he listens to the song for the first time he searches the children with great agitation, as stated in Aidoo's stage directions, unknowing if they were real kids or just a dream:

Afternoon sleep always brings me afternoon dreams, horrid, disgusting, enigmatic dreams. Damn this ghost at the junction. I loved to sing that song. Oh yes, I did. But it is all so long ago. I used to wonder what the ghost was doing there at the junction. And I used to wonder too what it did finally ... Did it go to Elmina or to Cape Coast? And I used to wonder, oh, I used to wonder about so many things then. But why should I dream about all these things now? Probably I am going mad. (Dilemma 29)

Aidoo's description of the male child is a clear representation of the young Ato, in fact the description of the playwright for the character of the boy is "The

\footnotetext{
${ }^{6}$ A 'been-to' is a man who has been to a western country and on his way back to Africa he is welcomed as if he belonged to a higher social status. Unlike men, 'been-to' women do not usually receive these social privileges.
} 
boy being the ghost of Ato's former self' (Dilemma 3). Moreover, his reaction to the song depicts his unstable behaviour. At this point of the play, Ato is unable to deal with the consequences of the comeback home and, in fact, this process does not only affect himself and his relation to his family, but the patriarchal and imperialistic manners Ato acquired in his exile prevents him from letting his African American wife join her new family.

Eulalie just knows the clichés of Africa, as “Africa, the Dark Continent, was a label which endured for many years, owing perhaps to 'Europe's and America's own ignorance of an uncharted wilderness beyond [their respective] coasts' (Lewis 23)" (Allen 261). Additionally, she only speaks English, thus every time she wants to say something she uses Ato as an interpreter. In this way, Ato is able to control every situation and prevent Eulalie from adopting the matrilineal system of his family. As Horne collects, in matrilineal societies

acknowledging mothering as the locus of social, economic, and political organization in the human community, through the tracing of descent and the inheritance of political power via the mother line, the matrilineal kinship system recognizes women's multiple subjectivity emanating form maternal agency. (304)

This would have led Eulalie to become, socially speaking, a more important member in the family than Ato, what in the eyes of her husband would mean losing his patriarchal and neo-colonial rule over his wife and his family. At the same time, his family and community do not understand Eulalie's ways and make her responsible of all the problems that arise between them and the couple. Eulalie is blamed for Ato's wrong deeds, above all for the economical ones:

The vulture, right from the beginning wallows in the soup he will eat. Have your Hureri [Eulalie] got all her machines now? 'Hureri must have a sutof. Hureri must have something in which to put her water to cool. Hureri, Hureri. Oh, the name keeps buzzing in my head like the sting of a witch-bee! (Dilemma 36)

This lack of understanding helps Ato to keep his domain over both his family and his wife until his family begins to understand Eulalie's real situation.

Nevertheless, the family's rejection to Eulalie is not only related to an economic question or to the misunderstandings created by Ato's interference, but to the fact that she reminds them of the past and to the memories she arises as a daughter of the diaspora. In order to raise this question Aidoo serves herself of a powerful element, the previously mentioned song titled 'The Ghost', which is more than a children's song: 
One early morning, / When the moon was up / Shining as the sun, / I went to Elmina Junction / And there and there, / I saw a wretched ghost / Going up and down / Singing to himself / 'Shall I go / To Cape Coast, / Or to Elmina / I don't know, / I can't tell. / I don't know, / I can't tell' (Dilemma 28)

Her decision of choosing the two locations that appear in the 'insignificant' song is not random at all. Elmina and Cape Coast were two of the most important slavery towns and slavery ports in Ghana, so this is how Aidoo addresses the question of slavery and diaspora in a much deeper way. When Ato comes back to Ghana and explains to his family that he was married to an American woman, their first reaction is to think she is white. Their greatest worries are related to not being able to understand neither what Ato is explaining nor her ways: "we do not know the ways of the white people. Will not people laugh at us? [...] you must tell us properly. We do not know" (Dilemma 17). Ato's reaction responds to his imperialistic manners; he is nervous and impatient and he does not stand the fact that his family do not understand. When he is finally able to explain them that Eulalie is black because "Eulalie's ancestors were of our ancestors. But as you all know; the white people came and took some away in ships to be slave..." (Dilemma 18) his family understands that Eulalie is actually a slave. Aidoo emphatically presents the characters' desperate reactions in the stage directions "At this point even the men get up with shock from their seats. All the women break into violent weeping. Esi Kom is beside herself with grief. She walks round in all attitudes of mourning" (Dilemma 18). Ato tries to explain them that "[i]t was her grandfathers and her grandmothers who were slaves" (Dilemma 18), but his family's answer ends the conversation: "Ato, do not talk with the foolishness of your generation" (Dilemma 18). For Ato's family Eulalie represents the ghost of slavery, she will always remind them of a past they do not want to assimilate. She is, according to the grandmother, "the offspring of slave. A slave" (Dilemma 19), and Ato "[h] as gone away and brought to their sacred precincts / The wayfarer!" (Dilemma 19).

As a daughter of the diaspora, Eulalie is willing to travel to Africa because she lacks her African origin. In a subconscious way Eulalie does not want to create a family of her own with Ato, but she is trying to belong to an African family through her marriage to him; that would mean recovering what her diasporic situation snatched from her. As Hill-Lubin collects, this topic of the "reconnection of African [American] peoples with their history, their past, and with each other" (46-47) is common in other writers like Paule Marshall, whose works "have emphasized the need of the African in exile to make a journey back through history in order to achieve wholeness" (47) in a physical and/or spiritual journey. 
In fact, as C. L. Innes and Maureen N. Eke point out, for Eulalie "[t]he return is a journey back to origins to seek a nation of her own, a 'lost homeland and lost mother' (Innes 34)" (Eke 70). Thus, Africa becomes Eulalie's exile, the land that symbolizes what she desires the most, a home.

Ato's matrilineal society, Akan society, is in Aidoo's words "one of the most matriarchal societies in West Africa" (Maja-Pearce 17). In fact, "most African societies were matrilineages lasting millennia, from the prepharonic period all the way down to a micronation like the Akans of Ghana" (Aidoo, The African 42). As Horne collects "Mothering ... is conceived to be the encompassing socio-political and spiritual foundation of human organization" (304), hence one of the most important roles of women in Akan society is choosing the wives for their sons and grandsons; this is the way they have of selecting who is going to be the mother of the future generation. In Aidoo's play, Ato comes back to Ghana with a wife nobody chose and this becomes an important problem between the couple and the family.

Moreover, considering the importance of motherhood in the Akan society, as it was the most important way women had of exerting some power in their family and society, not being able to have children meant being rejected by your husband and your family-in-law. A woman with no children did not meet with the expectations of the community, as "barrenness distinguishes her from every other woman, every other normal woman anyway, and as such she is not-woman, she loses her feminine identity with her maternal identity" (O'Brien 97). The problematic question of motherhood directly affects Eulalie's situation and her relation to her family-in-law. Ato's family expects the couple to have children as soon as possible because "[w]hen two people marry, everyone expects them to have children. For men and women marry because they want children" (Dilemma 44). When a year goes by and Eulalie does not get pregnant, the family worries and thinks she may be sterile. In fact, as the couple buys many electrical devices for their home, the family thinks they are trying to compensate this lack of children with material goods: "This is very hard to understand. [...] the young people of the coming days are strange ... very strange. [...] But this is too large for my head or is the wife pregnant with a machine child?" (Dilemma 38-39). Even some members of the community, like a sterile neighbour, feel sorry for Ato's wife, highlighting the difficulties a woman without children usually bears:

Barren! ... If it is real barrenness, then, oh stranger-girl, whom I do not know, I weep for you. For I know what it is to start a marriage with barrenness. [...] They want people. My people have a lusty desire to see the tender skin on top of a child's scalp rise and fall with human life. [...] For my world which you have run to enter is most unkind to the 
barren. And for you - who shall talk for the stranger? My daughter or my sister, whom I have never set eyes upon, you will cry until your throat is dry and your eyes are blind with tears. Yes, my young woman, I shall remember you. I shall remember you in the hours of the night in my sleep, in my sleepless sleep. (Dilemma 39-40)

The opinions and attitudes of Ato's family emphasise how this assumed sterility affects Eulalie's adaptation to the family. As sterility is the only possible reason the family has to explain the lack of children they decide to find a solution and go to talk to the couple to know "what is preventing [them] from giving [their] grandmother a great-grandchild before she leaves [them]" (Dilemma 43). Although Eulalie was aware of the importance of children in Africa, she did not understand that motherhood was the way to fit in with Ato's family, and not marriage. As Horne describes, the fact that Ato and Eulalie had children would be helpful to improve their relation with the family and would lead Eulalie to a complete integration, as "Eulalie becoming the instrument for bringing about this realization will engender her connectedness to Ato's family, mitigating the alienating circumstances surrounding Ato's marriage" (Horne 313).

During the visit the family pays, Aidoo makes reference again to the lack of understanding between the family and Eulalie's habits. The family thinks the reason why Eulalie does not get pregnant is that she smokes and drinks alcohol, so they want to clean her stomach. This visit entails an argument between the couple that leads to the truth of the matter. Eulalie discovers that her family-inlaw thinks she is sterile and that Ato did not explain them the real reason of their lack of children: "Why don't you tell them you promised me we would start having kids when I wanted them?" (Dilemma 47). At the same time, Aidoo reflects that the lack of understanding of Ato's family is not a problem of the family but it is due to the role Ato is playing as a neo-colonial master over his family and wife. Ato's mother is aware of the changes within society and she accepts them because "[t]hese days, one's son's marriage affair cannot always be one's affair" (Dilemma 42). And, although the grandmother resists these new views and insists that "[i]t may be so in many homes. [But] Things have not changed here" (Dilemma 42), Aidoo resolves that if Ato had explained them the decision of the couple, they would have understood them and accepted Eulalie.

As I have previously suggested, Eulalie desires to belong, both to Africa, in a general sense, and to an African family that would connect her to her roots. For this reason, when Eulalie discovers that Ato has been preventing her from having a normal relation with her family-in-law she leaves him. This is what leads Ato to talk to his mother and, at this point, he is once again identified with the ghost of the song, as the neighbours say his figure "looks like a ... ghost" (Dilemma 48). 
Although Ato tries to blame Eulalie yet again, his mother finally understands what has been going on when Ato confesses to his mother that "[Eulalie's] womb has not receded!" and that "If [they] wanted children, she would have given birth to some" (Dilemma 51). Esi's ignorance of contraceptives is clearly addressed "Ei, everyone should come and listen to this. I have not heard anything like this before ... Human beings deciding when they must have children?" (Dilemma 51), and despite she first accuses them both of lying, she understands Eulalie was wrongly blamed for every single problem the family had with Ato when she was not responsible at all:

... and yet who can blame her? No stranger ever breaks the law... Hmm...my son. You have not dealt with us well. And you have not dealt with your wife well in this. [...] before the stranger should dip his finger into the thick palm nut soup, it is a townsman must have told him to. And we must be careful with your wife you tell us her mother is dead. (Dilemma 51-52)

Throughout this play, Aidoo denounces the consequences that going to the exile and coming back had in African families. The main two characters belong to two different cultural backgrounds, which influence the differences in their reactions and experiences in Africa. Aidoo serves herself of these characters and of the fighting between a patriarchal and a matrilineal conception of family to represent the feelings of unrootedness and guilt that surround these questions of exile and diaspora. Considering that the male character, Ato, has never really wanted to return to Africa, together with the prejudices his Ghanaian family have against his African-American wife, lead the couple to a feeling of unrootedness and the family to a feeling of guilt.

Presented as the main character at the beginning of the play Ato is set as an outcast at the end of it, where Aidoo's stage directions show the character "looks bewildered and lost" (Dilemma 52). In spite of having been the link between his community and the children of diaspora-as he did not have any prejudice against marrying an African American and bringing her to Africa-he has lost his African identity in favour of a neo-colonial attitude. In the last lines of the play the children appear again singing "Shall I go to Cape Coast / Shall I go to Elmina? / I can't tell / Shall I? / I can't tell..." (Dilemma 52). Although Eulalie may have represented the ghost of the diaspora for the family and the community, it is Ato the one who represents the ghost that is physically and psychologically between two different worlds and, as the ghost of this insignificant song, he is unable to choose. His neocolonial attitude leaves no space for in-betwenness; moreover, it prevents him from knowing what to do or how to behave anymore and hence his future is indeterminate. In the case of Eulalie, although her relationship with Ato does not 
seem to succeed, the fact that at the end of the play Esi addresses her "Come, my child" (Dilemma 52) while the stage directions describe how Esi "rushes forward to support her on [and] supports Eulalie through the door that leads into the old house" (Dilemma 52) establishes that she is finally accepted as a member of the family and community, as a member of the big African family, that is what she had always wanted. Despite the fact that not being barren opens up the possibility of providing the family with children, and this influences Esi in accepting Eulalie, Aidoo goes a step further. With this final union between both women Aidoo presents a possible solution against the rejection to the children of the diaspora on the one hand, and a possible solution against patriarchal oppression on the other. These female characters, the real protagonists of the story, are able to reconcile both worlds, the traditional and the modern one, and therefore contrast with the lost figure of Ato.

Samuel Yaw Asante reminds us that the role of African women as transmitters of traditional culture, as story-tellers, was that of "custodians of oral histories and indigenous forms of knowledge" (203). Asante insists on claiming that despite " $[\mathrm{t}]$ he introduction of colonial education eroded the position of women as custodians of our culture ... [African] women writers' texts repossess and maintain a tradition that colonial education eroded" (203). Following this idea and keeping in mind that The Dilemma of a Ghost is a play to be staged, I strongly believe that Aidoo appropriates this role of story-teller and lets her audience learn about the problems caused by Ato's return from the exile and by the nonacceptance of a diasporic past, presenting the final acceptance and understanding of both women as an example. Thus, the audience is the one responsible of breaking the silence and distinguishing what is 'significant' and what is not.

\section{WORKS CITED}

Aidoo, Ama Ata. Our Sister Killjoy or Reflections from a Black-eyed Squint. 1977. Hong Kong: Longman, 1990.

---. "The African Woman Today." Sisterhood, Feminisms and Power: From Africa to the Diaspora. Ed. Obioma Nnaemeka. Trenton, NJ: Africa World Press, 1998. 39-50.

---. The Dilemma of a Ghost. 1965. New York, NY: Longman African Writers, 2005.

Journeys of the Slave Narrative in the Early Americas. Ed. Aljoe, Nicole N., and Ian Finseth. University of Virginia Press. Web. 29 Apr. 2016. <http://www.jstor.org/stable/j.ctt7zwdbx>. 
Allen, Deborah. "The Image of Africa in North American Children's Literature." The Growth of African Literature: Twenty-Five Years after Dakar \& Fourah Bay. Eds. Edris Makward, Thelma Ravell-Pinto and Aliko Songolo. Trenton, NJ: Africa World Press, 1998. 261-71.

Asante, Samuel Yaw. In My Mother's House: A Study of Selected Works by Ama Ata Aidoo and Buchi Emecheta. Calgary: University of Calgary, 2000. $\mathrm{PhD}$ dissertation. Web. 9 Sep. 2008. <http://dspace.ucalgary.ca/handle/1880/ 39677?mode=full >.

Baker, Houston A. The Journey Back: Issues in Black Literature and Criticism. Chicago: University of Chicago Press, 1980.

Christopher, Emma, Cassandra Pybus, and Marcus Rediker. Eds. Many Middle Passages: Forced Migration and the Making of the Modern World. Berkeley and Los Angeles, CA, London, England: University of California Press, 2007. Web. 29 Apr. 2016. <http://www.jstor.org/stable/10.1525/j.ctt1ppmd0>.

Delpino, Gaia. "Building Up Belonging: Diasporic 'Homelands', the Ghanaian Government and Traditional Rulers: A Case of Return." African Diaspora 4 (2011): 163-84.

Eke, Maureen N. "Diasporic Ruptures and (Re)Membering History: Africa as Home and Exile in Anowa and The Dilemma of a Ghost." Emerging Perspectives on Ama Ata Aidoo. Eds. Ada U. Azodo and Gay Wilentz. Trenton (NJ): Africa World Press, 1999. 61-78.

Eltis, David, and David Richardson. Atlas of the Transatlantic Slave Trade. New Haven: CT: Yale University Press, 2010. Web. 29 Apr. 2016. <http://www.jstor.org/stable/j.ctt5vm1s4.4>.

Emecheta, Buchi. In the Ditch. London: Barrie \& Jenkins, 1972.

---. Kehinde. Reading: Heinemann, 1994a.

---. Second-Class Citizen. 1974. Reading: Heinemann, 1994b.

"Exile." Def. 1. The Oxford English Dictionary. Oxford Dictionaries. Oxford U.P., 2012. Web. 14 Dec. 2012. < http://www.oed.com/>.

Fanon, Frantz. The Wretched of the Earth. Trans. Constance Farrington. Harmondsworth: Penguin, 1967.

Gikandi, Simon. "African Literature and the Colonial Factor." African Literature. An anthology of criticism and theory. Eds. Tejumola Olaniyan and Ato Quayson. Cambridge: Blackwell, 2007. 54-59.

---. "Introduction: Africa, Diaspora, and the Discourse of Modernity." Research in African Literatures 24.4 (1996): 1-6.

Gilroy, Paul. The Black Atlantic: Modernity and Double Consciousness. Cambridge: Harvard U.P., 1993.

Hill-Lubin, Mildred A. "Ama Ata Aidoo and the African Diaspora: Things, 'All Good Men and Women Try to Forget,' but I Will Not Let Them". Emerging Perspectives on Ama Ata Aidoo. Eds. Ada Uzoamaka Azodo and Gay Wilentz. Trenton, NJ: Africa World Press, 1999. 45-60.

Hope-Scott, Joyce. "The Animal Trickster as Political Satirist and Social Dissident: An Analysis of Leuk-the-Hare in Birago Diop's Tales of Amadou Koumba and Br'er Rabbit in the Afro-American Folk 
Tradition." The Growth of African Literature: Twenty-Five Years after Dakar \& Fourah Bay. Eds. Edris Makward, Thelma Ravell-Pinto and Aliko Songolo. Trenton, NJ: Africa World Press, 1998. 249-59.

Horne, Naana B. "The Politics of Mothering: Multiple Subjectivity and Gendered Discourse in Aidoo's Plays." Emerging Perspectives on Ama Ata Aidoo. Eds. Ada U. Azodo and Gay Wilentz. Trenton, NJ: Africa World Press, 1999. 303-31.

Innes, C. L. "Mothers or Sisters? Identity, Discourse and Audience in the Writing of Ama Ata Aidoo and Mariama Bâ." Motherlands. Ed. Susheila Nasta. London: The Women's Press, 1991. 129-51.

James, Adeola. “Ama Ata Aidoo." In Their Own Voices: African Women Writers Talk. London: Heinemann, 1990.

Levitov, Betty B. Social Theory and Literary Sources in the Novel of Buchi Emecheta (Nigeria). Lincoln: University of Nebraska, 1983. PhD $\begin{array}{llll}\text { dissertation. } & \text { Web. } & 11 & \text { Sep. }\end{array}$ $<$ http://proquest.umi.com/pqdlink?vinst=PROD\&attempt= $1 \& \mathrm{fmt}=14 \&$ startpage $=-1 \&$ ver $=1 \&$ vname $=$ PQD $\&$ RQT $=309 \& \mathrm{did}=$ 748963111\&exp=09-10-2013\&scaling $=$ FULL\&vtype=PQD\&rqt= $309 \& \mathrm{cfc}=1 \& \mathrm{TS}=1221127902 \& \mathrm{clientId}=58317>$.

Lewis, Freda. "Darkness Was in Our Vision." New York Times 18, (Jan. 1989): sec. 1:23.

Lima, Robert. "The Orishas: African Deities in Cuban Literature." The Growth of African Literature: Twenty-Five Years after Dakar \& Fourah Bay. Eds. Edris Makward, Thelma Ravell-Pinto and Aliko Songolo. Trenton, NJ: Africa World Press, 1998. 273-81.

Lindfors, Bernth. "The Image of the Afro-American in African Literature." Association for Commonwealth Literature and Language Studies Bulletin 4, 3 (1975): 19-26.

Maja-Pearce, Adewale. "We Were Feminists in Africa First. Interview with Ama Ata Aidoo." Index on Censorship 19, 9 (October 1990): 17-18.

Mugo, Micere Githae. "Exile and Creativity: A Prolonged Writer's Block." African Literature. An anthology of criticism and theory. Eds. Tejumola Olaniyan and Ato Quayson. Cambridge: Blackwell, 2007. 144-49.

Ngugi wa Thiong'O, "Writing Against Neo-Colonialism." African Literature. An anthology of criticism and theory. Eds. Tejumola Olaniyan and Ato Quayson Cambrigde: Blackwell, 2007. 164-175.

O'Brien, Louise. "Buchi Emecheta and the "African Dilemma." The Journal of Commonwealth Literature. (2001). Web. 24 Jul. 2008. $<$ http://jcl.sagepub.com/cgi/reprint/36/2/95>.

Ogot, Grace. The Graduate. Nairobi: Uzima Press Ltd, 1980.

Pedersen, Carl. "Middle Passages: Representations of the Slave Trade in Caribbean and Africa-American Literature." The Massachusetts Review, 34.2 (Summer 1993): 225-238. Web. 29 Apr. 2016. <http://www.jstor.org/stable/25090419>.

Schramm, Katharina. "Negotiating Race: Blackness and Whiteness in the Context of Homecoming to Ghana." African Diaspora 2 (2009): 3-24. 
Smallwood, Stephanie E. Saltwater. Slavery: a middle passage from Africa to American Diaspora. Cambridge, Massachusetts: Harvard University Press, 2008.

Wilentz, Gay. "The Politics of Exile. Ama Ata Aidoo's Our Sister Killjoy." Arms Akimbo: Africana Women in Contemporary Literature. Eds. Janice Liddell and Yakini Belinda Kemp. Gainesville: Florida U.P., 1999. 16275 . 